\title{
Evaluation of the results of fine needle aspiration biopsy cytology on thyroid nodules and breast tumors at the Hasan Sadikin Hospital Bandung
}

Pisi Lukitto

\begin{abstract}
Abstrak
Telah pernah dilakukan dua penelitian, baik biopsi aspirasi jarum halus pada nodul tiroid, maupun pada tumor payudara. Tujuan penelitian ini adalah untuk mengetahui sensitivitas dan akurasi BAJH di Rumah Sakit Hasan Sadikin . Pada 167 di antara 250 kasus nodul tiroid, telah dilakukan pembedahan, dan 16 ternyata ganas. Pemeriksaan sitologik BAJH memberikan hasil 12 negatif palsu, 1 positif palsu, 4 positif benar, dan 150 negatif benar. Hasil diagnostik tes adalah sebagai berikut: sensitivitas 25\%, spesifisitas $99,3 \%$, nilai prediksi positif $80 \%$, nilai prediksi negatif $92,6 \%$, dan akurasi $92,2 \%$. Pada penelitian yang lain terhadap 41 kasus tumor payudara, ditemukan hasil 2 negatif palsu, tidak ada positif palsu, 35 positif benar, dan 4 negatifbenar. Hasil diagnostik tes adalah sebagai berikut: sensitivitas $94,6 \%$, spesifisitas $100 \%$, nilai prediksi positif $100 \%$, nilai prediksi negatif $66,7 \%$, dan akurasi $95,1 \%$.
\end{abstract}

\begin{abstract}
Two studies of FNAB have been performed on thyroid nodules and breast tumors respectively. The aim of the studies was to test the sensitivity and accuracy of FNAB in the Hasan Sadikin Hospital. Among 250 cases of thyroid nodules, 167 underwent surgery, and 16 revealed malignancy. The FNAB cytology results were 12 false negative, one false positive, 4 true positive, and 150 true negative. The cytology results of $\mathrm{FNAB}$ were as follows: $25 \%$ sensitivity, $99,3 \%$ specificity, $80 \% . \mathrm{PV}^{+}, 92,6 \% \mathrm{PV}^{-}$, and $92,2 \%$ accuracy. In another study of 41 cases of breast tumors we found 2 false negative, no false positive, 35 true positive, and 4 true negative. The FNAB cytology results were as follows: $94,6 \%$ sensitivity, $100 \%$ specificity, $100 \% \mathrm{PV}^{+}, 66,7 \% \mathrm{PV}^{-}$, and $95,1 \%$ accuracy.
\end{abstract}

Keywords : FNAB, thyroid nodules, breast tumors

Fine needle aspiration biopsy (FNAB) cytology, the minimal-invasive procedure as a diagnostic tool in human malignancies have been used worldwide since its introduction in the early 1950's in Scandinavian countries. The utility of FNAB have been highly used, and nearly becomes a trend in the world since it is a simple, quick, and inexpensive method to biopsy superficial masses, usually in the office or clinic setting. It causes minimal trauma to the patient and carries virtually no risk of complications. ${ }^{1}$

The principal indication for FNAB of the thyroid is a solitary thyroid nodule. A classic multinodular gland is rarely suspicious for carcinoma. ${ }^{2}$ FNAB has become an extremely popular technique for the evaluation of solitary thyroid nodules. Most papillary carcinomas and other types of malignancy other than follicular carcinoma can be easily identified. Beside the poor cellularity of the specimen as a general problem in

Division of Surgical Oncology, Head and Neck Surgery, Department of Surgery, Faculty of Medicine, Padjadjaran University/Hasan Sadikin Hospital, Bandung, Indonesia
FNAB due to an inexperienced physician as a provider, the main difficulty (and this is specific problem for thyroid nodules) is in the identification of a well differentiated follicular carcinoma that may be impossible with this method. The identification of a follicular type of thyroid carcinoma, largely depends on the presence of invasion of the capsule, blood vessels, or adjacent normal thyroid tissue. Foci of capsular invasion should be distinguished from capsular rupture resulting from a fine-needle aspiration procedure. Cytological interpretation of a follicular neoplasm are distinguished from a benign nodule only by the higher cellularity of normal follicular cells, which may be very subjective. ${ }^{3}$

In breast tumors along similar lines, it is generally not possible to distinguish between in situ and invasive ductal carcinoma on FNAB. The most significant variables in the accuracy of the FNAB procedure are size of the lesion and proficiency of the individual performing the aspiration. FNAB is less than ideal for some types of carcinoma, like extensive fibrosis, intraductal carcinoma, tubular and cribiform carcinoma, and in general, the very small tumors. 
To know whether FNAB cytology could be used routinely according to its sensitivity and accuracy in the Hasan Sadikin Hospital, the two former studies which have been performed in Bandung were reevaluated. First the study about its utility in diagnosis of malignancies of thyroid nodules, and second the study about its utility in diagnosis of malignancies of breast tumors.

\section{METHODS}

Two phases of studies which have been performed in the Department of Surgery, Hasan Sadikin Hospital Bandung, were compared. During the first phase there were 250 patients with thyroid nodules which were aspirated and sent for cytological examination, among which 167 patients underwent thy roidectomy. The last specimens were sent for histopathological examination. The cytological findings and histopathological diagnoses were compared blindly. The surgical procedures were hemithyroidectomy for unilateral nodules and hemithyroidectomy plus subtotal lobectomy of the contralateral side in bilateral nodes. If the histopathological finding revealed malignancy, then total thyroidectomy was performed. ${ }^{5}$

At the second phase, 41 breast tumor cases were studied by FNAB cytology. The sample inclusion were new cases of breast tumor which were clinically malignant with a diameter of more than $2 \mathrm{~cm}$. Inoperable cases underwent incisional biopsy, while operable cases underwent radical mastectomy, and the specimens were sent for routine histopathological examination. The cytological and histopathological findings were compared blindly. ${ }^{6}$

The method of aspiration technique was the same for both thyroid nodules as well as breast tumors. The written informed consent for FNAB was done before the procedure was performed as recommended by the National Cancer Institute Conference in USA. ${ }^{7}$ With a $20 \mathrm{ml}$ disposable syringe and a $22-23 \mathrm{G}$ needle, aspiration was performed in thyroid nodules or breast tumors as one puncture at 3 different places. After the needle introduction to the tumor, the plunger was retracted to create a vacuum in the syringe. With the plunger still in that position, the needle was moved back and forth in different directions under constant suction in order to detach the tissue fragments. In this position the needle was withdrawn from the nodule. The needle containing the sample was detached from the syringe, and the content of the needle was blown out on a microscope slide by pushing down the plunger. By using another slide the specimen was then smeared thoroughly.

Sensitivity, specificity, positive predictive value $\left(\mathrm{PV}^{+}\right)$, negative predictive value $\left(\mathrm{PV}^{-}\right)$, and accuracy of the two studies were calculated, according to the standard formulas: ${ }^{8}$

Sensitivity $=\frac{\text { true-positives }}{\text { true positives +false negatives }} \times 100 \%$
Specificity $=\frac{\text { true-negatives }}{\text { true-negatives +false-positives }} \times 100 \%$
$\mathrm{PV}^{+}=\frac{\text { true-positives }}{\mathrm{PV}^{-}=\frac{\text { true-positives }+ \text { false-positives }}{\text { true-negatives }} \times 100 \%}$
Accuracy $=\frac{\text { true-negatives }+ \text { false-negatives }}{\text { true-negatives }+ \text { true-positive }}$

\section{RESULTS}

The cytological findings in 167 thyroid nodule cases were 5 positive malignant and 162 negative, but after thyroidectomies the histopathological findings were 16 positive malignant and 151 negative. One case which was considered malignant on cytological examination, turned out to be negative on histopathological examination (false positive), and 12 cases which were considered negative on cytological examination turned out to be positive on histopathological examination (false negative). That means the sensitivity was only $25 \%$, specificity $99,3 \%, \mathrm{PV}^{+} 80 \%, \mathrm{PV}^{-} 92,6 \%$, and the accuracy was $92,2 \%$.

In 41 breast tumor cases which clinically were suspected malignant, the cytological findings were 35 positive, and 6 negative. After open biopsy for inoperable cases and mastectomy for operable ones, the histopathological examination revealed 37 positive and 4 negative. False negative FNAB cytology results were found in 2 cases, and no false positive. The sensitivity revealed $94,6 \%$, specificity $100 \%, \mathrm{PV}^{+}$ $100 \%, \mathrm{PV}^{-} 66,7 \%$, and accuracy $95,1 \%$. 
Table 1. The outcome of cytological (FNAB) and histopathological (biopsy) tests of thyroid nodules

\begin{tabular}{lrrr}
\hline FNAB cytology & \multicolumn{2}{c}{ Histopathological results } & \multirow{2}{*}{ Total } \\
\cline { 2 - 3 } & Malignant & Non malignant & \\
\hline Positive & 4 & 1 & 5 \\
Negative & 12 & 150 & 162 \\
\hline Total & 16 & 151 & 167 \\
\hline
\end{tabular}

Table 2. Accuracy of FNAB cytology results in malignancy on thyroid nodules

\begin{tabular}{ll}
\hline & \multicolumn{1}{c}{ malignancy on thyroid nodules } \\
\cline { 2 - 2 } Sensitivity (\%) & 25 \\
Specificity (\%) & 99,3 \\
PV $^{+}(\%)$ & 80 \\
PV $^{-}(\%)$ & 92,6 \\
Accuracy (\%) & 92,2 \\
\hline
\end{tabular}

\section{DISCUSSION}

FNAB cytology alone as a diagnostic tool for a thyroid nodule was unreliable in detecting thyroid malignancies. Fraker et al $^{9}$ suggested that the management decisions in thyroid nodules could be based on the FNAB cytology results as long as it is combined with the clinical history. The accuracy of cytological diagnosis is highly dependent on the skill of the person performing the biopsy and the cytopathologist interpreting it.

Table 3. The outcome of cytological (FNAB) and histopathological (biopsy) tests of breast tumors

\begin{tabular}{lccr}
\hline FNAB cytology & \multicolumn{2}{c}{ Histopathological results } & Total \\
\cline { 2 - 3 } & Malignant & Not malignant & \\
\hline Positive & 35 & 0 & 35 \\
Negative & 2 & 4 & 6 \\
\hline Total & 37 & 4 & 41 \\
\hline
\end{tabular}

Table 4. Accuracy of FNAB cytology results in malignancy of breast tumors

\begin{tabular}{lc}
\hline & malignancy in breast tumors \\
\cline { 2 - 2 } Sensitivity (\%) & 94,6 \\
Specificity (\%) & 100 \\
PV $^{+}(\%)$ & 100 \\
PV $^{-}(\%)$ & 66,7 \\
Accuracy (\%) & 95,1 \\
\hline
\end{tabular}

In our thyroid serries, FNAB cytology had a very low sensitivity $(25 \%)$. That means FNAB cytology in the Hasan Sadikin Hospital is not sensitive enough to detect malignancy in a thyroid nodule. The high accuracy $(92,2 \%)$ obtained might be due to the high true negative FNAB cytology result (150/167). False negative in this series was $12 / 167(7,2 \%)$, which was high enough compared to $2,2 \%$ false negative in Lowhagen's series. ${ }^{10}$ Based only on the FNAB cytology results, we should not perform surgery to those patients according to the negative results. We considered that it will be a risk for the patients, because they will still have a malignancy in their body which was not yet detected.

According to Caruso et al, ${ }^{11}$ the accuracy of cytological diagnosis of thyroid nodules from FNAB range from $70 \%$ to $97 \%$ and was highly dependent on the skill of the person performing the biopsy and that of the cytopathologist interpreting it. The result of FNAB were most commonly divided into the following categories: benign or negative, suspicious or indeterminate (including all follicular neoplasms or those with extensive Hurthle cell changes), malignant (papillary, anaplastic, medullary, and lymphoma), and insufficient sample. Their review of this technique provided insight into the results typically obtained at the time of fine-needle biopsy of the nodules: $70 \%$ benign, $4 \%$ malignant, $10 \%$ suspicious, and $17 \%$ as insufficient sample. Maxwell et al ${ }^{12}$ assessed the use and usefulness of FNAB in their hospital in Chapel Hill, North Carolina, and found that FNAB in the workup of patients with thyroid masses is strikingly underutilized, while accurate in $90 \%$ of cases where used, FNAB appears to play a minor role in the surgeon's decision regarding surgery.

Our study showed that FNAB on thyroid nodules resulted in: $89 \%$ benign, $2,3 \%$ malignant, $0,5 \%$ false positive, and $7,2 \%$ false negative, and the accuracy $92,2 \%$.

According to Carter, ${ }^{13}$ there are three types of material from the breast which can be cytologically examined. These include nipple secretions, material aspirated from cysts, and material aspirated from solid tumors. Aspiration of solid nodules of the breast is highly productive of material that has good residual morphology compared to material aspirated from nipple secretion and from the cysts. This matter could become the explanation of the second phase of our study in breast (solid) tumors FNAB, where the cytological results were as follows: $85 \%$ malignant, $9,7 \%$ benign, $4,8 \%$ false negative, and none false positive. 
A main issue of FNAB alone in detecting breast carcinoma is the false negative result. The low cellularity and poorly preserved specimen have been responsible for falsely atypical suspicious lesion in the rate of $1,2 \%$ to $1,6 \%$. In a review of the literature, the range of false negative breast FNAB in palpable breast lesions varies from $1 \%$ to $31 \%$, with an average rate of $10 \%$. This rate definitely can be reduced by gaining experience in the technique as well as interpretation of breast cytology. False positive findings have reduced the range from $0-11 \%$ to $0,1-0,2 \%$ in an experienced hand, which is similar to that reported for frozen section examination. ${ }^{14}$ Blichert-Toft et a ${ }^{15}$ on behalf of the European Society of Surgical Oncology (ESSO) suggested FNAB as a part of triple assessment in detecting breast carcinoma, together with the clinical findings and mammography. This triple assessment of breast lesions was also recommended at the National Cancer Institute Conference in Bethesda, Maryland, USA, September 1996, with representatives of the American Society of Cytopathology, Papanicolaou Society of Cytopathology, American College of Radiology, American College of Obstetricians and Gynecologists, Society of Surgical Oncology, American Academy of Family Physicians, College of American Pathologists, National Consortium of Breast Centers, International Academy of Cytology, American Society of Clinical Pathologists, American Cancer Society, American College of Surgeons, and the American Society of for Cytotechnology. ${ }^{7}$ Large series of FNAB have demonstrated a sensitivity of $87 \% .{ }^{16}$ Zajdela et al ${ }^{17}$ at the Foundation Curie-Institut found a total of 1529 of the $2772(55 \%)$ tumors were diagnosed as carcinoma by aspiration biopsy. After incisional biopsy, the diagnosis of aspiration biopsy was confirmed in all but three. FNAB therefore missed carcinoma in $12 \%$ of the cases. From February 1992 through December 1994, at the Magee-Womens Hospital Breast Care Consultation Center, there were 1418 cases evaluated, during which time only 366 FNABs were performed. The accuracy for positive diagnosis was $100 \% .{ }^{18}$

Our series of FNAB in breast tumors showed quite high in sensitivity and accuracy rate $(94,6 \%$ and $95,1 \%)$, even this was still a small series (41 cases). The specificity and $\mathrm{PV}^{+}$revealed $100 \%$ respectively because of the sample in this series were breast tumors which were clinically malignant. According to Masood $^{14}$ the diagnostic accuracy of breast FNAB significantly improved when a pathologist examined the patients before the procedure was performed. Proficiency in the biopsy technique, smear preparation, as well as the interpretation of the cytomorphology are the key factors for a successful FNAB.
Our studies showed that FNAB on thyroid nodules resulted in: $25 \%$ sensitivity, $99,3 \%$ specificity, $80 \%$ $\mathrm{PV}^{(+)}, 92,6 \% \mathrm{PV}^{(-)}$, and $92,2 \%$ accuracy, while the FNAB on breast tumors resulted in: $94,6 \%$ sensitivity, $100 \%$ specificity, $100 \% \mathrm{PV}^{(+)}, 66,7 \% \mathrm{PV}^{(-)}$, and $95,1 \%$ accuracy.

\section{Acknowledgement}

The author is grateful to his trainee in surgical oncology, Dr. Francisca Badudu, for all secretarial help in writing this paper, and also to Dr. Sjahir Ismail, as a cytological interpretator in the first phase study and to Dr. Sehabuddin, for data collecting in the second phase study. I am also indebted to Prof.Dr.Sutisna Himawan, and Dr. Santoso Cornain, for their commentary reading.

\section{REFERENCES}

1. Frable WJ. Fine Needle Aspiration Biopsy. In : Banks, PM, Kraybill, WG,editors. Pathology for surgeon.. Philadelphia: Saunders, 1996: 33-42

2. The Papanicolaou Society of Cytopathology Task Force on Standards of Practice. Guideline of the Papanicolaou Society of Cytopathology for the examination of fine-needle aspiration specimens from thyroid nodules. Modern Pathol 1996;9:710-5.

3. Rosai J. Ackerman's Surgical Pathology. $8^{\text {th }}$ ed. St. Louis: Mosby 1996: 493-567.

4. Rosai J. Ackerman's Surgical Pathology. $8^{\text {th }}$ ed. St. Louis: Mosby 1996: 1565-660.

5. Lukitto P, Ismail S, Iyad HA, Rosadi R. Fine needle aspiration biopsy for deciding the malignancy of a thyroid nodule in Hasan Sadikin Hospital Bandung. In: Tjokronegoro A Himawan S, Jusuf A, Susworo R, Aziz MF, Djakaria M/eds Cancer in Asia and Pacific: progress in clinical, epidemiological and biological aspects of cancer. Vol 1. Jakarta: Yayasan Kanker Indonesia, 1988:401-8.

6. Sehabuddin $H$. Nilai diagnostik biopsi aspirasi jarum halus (BAJAH) pada penderita tumor payudara yang secara klinis disangka ganas di RSU Dr. Hasan Sadikin Bandung (thesis). Bandung: Univ. of Padjadjaran, 1995.

7. Final version: the uniform approach to breast fine-needle aspiration biopsy. Breast J 1997;3(4):149-68.

8. Greenberg RS. Medical epidemiology. $1^{\text {st }}$ ed. London: Appleton \& Lange, 1993: 58-67

9. Fraker DI, Skarulis M, Livolsi V. Thyroid tumors. In DeVita VT, Hellman S, Rosenberg SA, eds. Cancer principle \& practice of oncology. $5^{\text {th }}$ ed. Philadelphia: Lippincot-Raven Publishers. 1997; 1629-52.

10. Lowhagen T, Gramberg PO, Lundell G, Shinnari P, Sunblad R, Willem JS. Aspiration biopsy cytology in nodules of thyroid gland suspected to be malignant. Surg Clin N Am. Philadelphia: Saunders 1979; 59(1):3-18.

11. Caruso D, Mazzaferi EL. Fine needle aspiration biopsy in the management of thyroid nodules. Endocrinologist 1991; 1: 194-6. 
12. Maxwell JG, Scallion RR, White WC, Kotwall CA, Pollock $\mathrm{H}$, Covington DL, et al. Fine needle aspiration cytology and thyroid surgery in the community hospital. Amer J Surg 1996; 172:529-35.

13. Carter D. Interpretation of breast biopsies. New York: Raven Press 1984:7-18

14. Masood S. Recent updates in breast fine-needle aspiration biopsy. Breast J 1996;2(1):3-12.

15. Blichert-Toft M, Smola MG, Cataliotti L, O’Higgins N. European Society of Surgical Oncology. Principles and guidelines for surgeons -management of symptomatic breast cancer. Eur J Surg Oncol 1997; 23:101-9.
16. Harris J, Morrow M, Norton L. Malignant tumors of the breast. In DeVita VT, Hellman S, Rosenberg SA, editors. Cancer principle \& practice of oncology. $5^{\text {th }}$ ed. Philadelphia: Lippincott-Raven 1997: 1557-67.

17. Zajdela A, Ghossein NA, Pilleron JP, Ennuyer A. The value of aspiration cytology in the diagnosis of breast cancer: experience at the Foundation Curie. Cancer 1975;35:499. 506.

18. Kanbour-Shakir A, Harris KM, Johnson RR, Kanbour AI. Breast care consultation center: role of the pathologist in a multidisciplinary center. Diag Cytopathol 1997;17(3): 191-6. 